Relations industrielles

Industrial Relations

\title{
Work and Employment in a Globalized Era: An Asia-Pacific Focus edited by Yaw A. DEBRAH and Ian G. SMITH, London: Frank Cass Publishers, 2001, 264 pp., ISBN 0-7146-5135-4 (cloth). Gerry Griffin
}

Volume 57, numéro 3, été 2002

URI : https://id.erudit.org/iderudit/006894ar

DOI : https://doi.org/10.7202/006894ar

Aller au sommaire du numéro

Éditeur(s)

Département des relations industrielles de l’Université Laval

ISSN

0034-379X (imprimé)

1703-8138 (numérique)

Découvrir la revue

Citer ce compte rendu

Griffin, G. (2002). Compte rendu de [Work and Employment in a Globalized Era: An Asia-Pacific Focus edited by Yaw A. DEBRAH and Ian G. SMITH, London: Frank Cass Publishers, 2001, 264 pp., ISBN 0-7146-5135-4 (cloth).] Relations industrielles / Industrial Relations, 57(3), 583-585.

https://doi.org/10.7202/006894ar

Tous droits réservés @ Département des relations industrielles de l’Université Laval, 2002
Ce document est protégé par la loi sur le droit d'auteur. L'utilisation des services d'Érudit (y compris la reproduction) est assujettie à sa politique d'utilisation que vous pouvez consulter en ligne.

https://apropos.erudit.org/fr/usagers/politique-dutilisation/ 


\section{Work and Employment in a Globalized Era: An Asia-Pacific Focus}

edited by Yaw A. DebraH and Ian G. SMITH, London: Frank Cass Publishers, 2001, 264 pp., ISBN 0-7146-5135-4 (cloth).

This book sets itself a very ambitious target: it wants to "bring to the fore the diverse impacts of globalization on work and employment in the Asia Pacific region." There are at least two immediate, related barriers to achieving this lofty ambition. First, the book draws on contributions to a broadly themed conference, in this case the $14^{\text {th }}$ Annual Employment Research Unit Conference organized by the Cardiff Business School at the University of Wales under the general title of "Globalization, Workplace and Employment: Responses for the Millennium." Almost inevitably, the products of such conferences are not sufficiently integrated to systematically attack ambitious targets. Second, the chapters are from the "best papers on the Asia-Pacific region". While there may be some imprecision about what is the Asia-Pacific region, an over-concentration on the English-speaking parts is not conducive to assessing the diverse impacts of globalization. Of the nine substantive chapters, four focus on Australia, one on New Zealand while another, the only cross-national paper, covers New Zealand and Singapore. Again, the exigency of the Conference borders the choice of chapters.

Rather than assess this book against its stated aim, it should be considered as a collection of papers focused on a limited number of countries in the Asia Pacific region. What then is of specific interest in this volume?

Focusing initially on the four Australian chapters, the issues analysed are the transformation of the coal industry, trade unions' response to HRM, a labour response to globalization and the link between cross-cultural diversity, leadership and workplace relations. The chapter on the coal industry traces supply and demand factors, the role of Japanese cartels in the global coal market and how the major coal union has attempted to respond to these influences. A wealth of solid industry data is included, though unfortunately ending with 1997 figures. Some company specifics are offered by way of a mini-case study of Rio Tinto, one of the leading mining companies. The chapter also makes the very important point that in Australia, the leading exporter of steam coal, intra-national competition can be as much the driver of change as international competition. Overall, this is a solid chapter that provides a useful introduction to industrial relations in a key Australian industry.

The contribution on union responses' to human resource management initiatives is a well-structured piece drawing on research at greenfield sites. It spends a lot of time on preliminaries, setting out different HR perspectives and the changing landscape of Australian industrial relations. Equally, much of the discussion of the fifteen case studies presents actual HR practices rather than union responses. Nevertheless, there are useful commentaries on what unions have achieved and are trying to achieve in what is, for them, a new environment.

The next two chapters are somewhat narrow and, in my view, largely for the cognoscenti. "Labour Responses to Globalization" is a discursive attack on the Accord, the social contract negotiated between a federal Labor government and the union movement between 1983 and 1996. The third sentence of this essay sets the tone: "under a neo-liberal, technocratic hegemony, the Australian Labor party of 1983-96 increased social inequity and drove Australia towards a possible Brazilian or Asian economic crisis." If you are an initiate of recent Australian industrial relations history, if you enjoy social contracts literature or if you are a devotee of technocratic discourse, this chapter may be of interest 
to you. The final Australian contribution tests the impact of transactional and transformational leadership on subordinates' levels of job satisfaction. Two groups of subordinates, drawn from four manufacturing plants, are examined: "Australian and Vietnamese cultural and subordinate groups." Unfortunately there is little explanation of what constitutes either group.

The next chapter should be of intrinsic value to many readers: the role of expatriate academics. Three main issues are analysed: cross-cultural training, cross-cultural adjustment and the roles of families. The conclusion, that the much broader literature on expatriate managers is of some relevance to expatriate academics, needs, however, to be qualified by the limited research basis: the fifteen interviews with expatriate academics in Singapore and "conversations" with a small number of academics in New Zealand are described as the preliminary findings of a larger $\mathrm{PhD}$ study. The second New Zealand contribution examines the impact of New Public Management on scientific research. Specifically, it assesses the implications of changing the public funding model from the traditional, untied block grant to accountable funding, and a growing reliance on private-sector funding. The key point made is that little attention was paid to the micro-level HRM implications of this change, particularly the impact on cultural change and the reward system. There is good solid material in this case study and its lessons are applicable to a much broader range of organizations.

The Malaysian contribution left me with many unanswered questions but it certainly whetted my appetite to learn more about the impact of Islam on work generally and HR practices specifically. The chapter comprises a case study of the employment practices of a governmentowned organization established to facilitate the participation of Malaysians in the Hajj, the pilgrimage to Mecca. With over 1,000 employees, the organization is, in effect, a combination of a bank, a travel agency and a property owner. Its HR practices are underpinned by a strong unitarist philosophy and appear very paternalistic; among other things, HR staff are prohibited from joining the company union. The authors recognize that this is a unique case study. Nevertheless, the claim that Islamic-influenced organizations better survived the 1997 Asian economic crisis is an intriguing argument. Future work on HR in SouthEast Asia will have to consider this religious dimension.

The first half of the chapter on employment issues in the Japanese service sector contains little that would be new to readers with even limited knowledge of the Japanese literature on employment practices. Indeed, most would probably now question the "lifetime security and stability" comment that appears in this part of the chapter. The remainder of the chapter reports the results of a questionnaire survey of managers in the service sector conducted in January 1998. This survey used the "what if" technique: specifically, how would these managers react if the existing labour law framework was relaxed. Based on responses, the author argues the case for deregulation of practices such as dismissal procedures and for the introduction of individual contracts.

The final contribution examines the role of guanxi, defined as personal kinship or friendship networks, in the job search processes adopted by graduating students in one Chinese university. The displacement of the traditional, government-allocated job has led to the growth of a number of different, more westernised job search patterns. However, despite this development and despite the gradual opening-up of the Chinese economy, the authors contend that guanxi are alive and well. One issue that is touched upon is the role of what are termed the Overseas Chinese in this job search process. Similar to the Malaysian 
case study and its reference to Islamic influences, the impact of the Overseas Chinese on HR practices points to the need for further research.

Overall, this compilation is somewhat disjointed and of variable standard, a fact well illustrated by the editors' valiant but doomed attempt in the concluding chapter to make some sense of, and linkage between, the disparate chapters. There are some good and useful papers in the collection, and some of them spark ideas. Given its conferencebased origins, the editors have done a reasonable job. At best, however, this book is one for the library rather than the personal bookshelf.

GERRY GRIFFIN Monash University

\section{Globalization from Below: The Power of Solidarity}

by Jeremy BRECHER, Tim Costello and Brendan SMITH, Cambridge, Mass.: South End Press, 2000, 154 pp., ISBN 0-89608-622-4.

Not long ago, Margaret Thatcher's triumphant "there is no alternative" to global neoliberalism echoed everywhere, the common sense of our times. That was before Seattle, Vancouver, Quebec City, Genoa, Washington, Prague, and Porto Alegre, and before what Naomi Klein calls the "most internationally minded, globally linked movement the world has ever seen." The successes of the movement for global justice are impressive. Not least are the victories against the Multilateral Agreement on Investment, the Free Trade Area of the Americas, and the World Trade Organization meetings in Seattle, the land mines agreement, and stopping the World Bank's Narmada dam project. Underlying these victories is the mobilization of a new political constituency across space and class around an array of global issues, from debt to sweatshops. For the authors of Globalization from Below the longer run significance of this new political formation lies in the convergence taking place among diverse movements: their overlapping memberships and concerns, increasing awareness of common interests, and their incessant networking around the world. This, they argue, is leading to an "historic break" defined by a choice between "globalization from above," engineered by corporate and state elites, and an internationalist, democratic and solidaristic "globalization from below."

The authors' starting point is that globalization from above fosters a "race to the bottom" in which countries compete with each other for trade and investment through privatization and deregulation, by offering tax and other incentives for investors, and by reducing labour standards and the social wage. This race is not only between the global North and South but often most destructively among Southern countries. In this context, globalization from below is entering a new phase. The main thesis of the book is that global justice movements must evolve past resistance to new forms of popular democratic control. This requires solidarity across national borders, identities and narrow and immediate interests. Hence the authors reject alliances with nationalist right wing movements in the U.S., France and elsewhere on the grounds that they are antagonistic to equality and democracy, and to labour, environmentalists, feminists, immigrants, racial and other minorities-in short, to much of the constituency of globalization from below. The authors are silent, however, about nationalist movements in parts of 